\title{
Remote Sensing Analysis In RUSLE Erosion Estimation
}

\author{
${ }^{1,3}$ Saptari, A.Y., ${ }^{2}$ Supriadi A., ${ }^{1,4}$ Wikantika K., ${ }^{1,4}$ Darmawan S. \\ ${ }^{1}$ Geodesy and Geomatic Department of Earth Science Faculty - ITB, Indonesia - \\ (aysaptari, ketut)@gd.itb.ac.id) \\ ${ }^{2}$ School of Life Science And Technology - ITB ; \\ ${ }^{3}$ Surveying and Cadaster Research Group - ITB \\ ${ }^{4}$ Center of Remote Sensing - ITB
}

\begin{abstract}
ABTRACT. Soil erosion is a major issue in various hemispheres. It is because erosion affects the survival of ecosystem. Diverse human actions, e.g., bushes burning and illegal logging, play a role in accelerating erosion. Climate factor such as rain intensity has also an influence in the release of soil particles. Therefore, a regular identification of those factors that affect erosion processes is highly needed in order to keep an environmental sustainable. Different areas in Indonesia have different erosion variable characteristics. One of the characteristics is indicated by the varieties of vegetation cover, where a loose vegetation cover causes soil surfaces open for a long time period. Till now, researches dealing with the modeling of erosions with wide area coverage are few, since erosion observations have always been conducted by direct observations in the field, hence time consuming. Therefore, an erosion mapping model that is applied in a wide coverage area and the up to date of data is needed. Spatially, erosions can be depicted in a form of spatial information system model describing their potential class levels. There are several erosion models that can be used to find out the erosion occurring on a land, among others Universal Soil Loss Equation (USLE) model or its modification Revised Universal Soil Loss Equation (RUSLE). RUSLE erosion model consists of rainfall, soil erodibility, vegetation cover, slope gradient and length, and support practice factors. Recent technology in remote sensing allowed vegetation cover to be analysed from satellite imagery, make the possibility of erosion analysis in large area in shorter time.
\end{abstract}

KEY WORD: Erosion, Vegetation, Models, Remote Sensing, RUSLE 


\section{Introduction}

Erosion is the loss of soil/release of parts of soil from one site transported by waters and winds to another (Seta,1987). In wet cilimate region, erosion caused by water is very important in erosion acceleration rate, and Indonesia is a tropical country with wet climate area in general (Arsyad,2010). Climate factors, e.g., rain intensity, affect detachment of soil particles. Rainsplash is the most important agent (Morgan,2005). Erosion causes the loss of fertile land layers that are good for plant growths and for keeping environmental conservation. Erosion acceleration has varying agronomic, ecologic, environmental, and economic impacts, occurring in both the location of erosion and beyond. Erosion has impacts on not only agricultural lands but also the quality of forests and dry farms (Blanco, 2008). Agricultural lands are more vulnerable to erosion threats because they are very often left in an open condition or without vegetation cover.

Various human's treating on a land caused some impacts on conservation quality, hence eventually a determinant of the erosion occurrence. The extent of erosion in a land can be estimated using a model. One of the models used in the present research was Universal Soil Loss Equation (USLE) model or its modification Revised Universal Soil Loss Equation (RUSLE) model likes in Alejandro,2007 ; Tao,2010; Gobena,2003. RUSLE is an estimation model of erosion comprising 6 factors : rain erosivity, erodibility, slope gradient, slope length, vegetation cover, and land conservatory actions called support practice (Arsyad, 2010). Vegetation cover in the erosion models can be analyzed from satellite imagery interpretation obtained by a remote sensing method, while support practice is considered as having a value of 1 mean that there is no conservatory action.

According to Meer and Jong (2004), Remote Sensing is a technology of gaining information on the characteristics of a phenomenon, object, or area by using electromagnetic (light) wave radiation without directly connecting with the object. It enables an analysis of the characteristics of vegetation cover by an analysis of electromagnetic waves reflected by the vegetation on earth surface represented in a form of images. This research used a remote sensing technology and Geographic Information System (GIS) to obtain information on erosion rate distribution. The remote sensing method was applied in processing Landsat TM data untill vegetation cover factor was gained; the data of slope length and gradient was generated from the data of Digital Elevation Models (DEM), soil erodibility factor was gained from soil types map; rain erosivity factor was gained from rainfall distribution; and support practice factor determined as 1 mean that no conservation treat implemented on land.

The research area was in part of Bandung basin that characterized with rapid changes in land cover within $7^{\circ} 15^{\prime} 0$ " $\mathrm{S}$ and $107^{\circ} 20^{\prime} 0^{\prime \prime} \mathrm{E}$ (Bottom-Left) and $6^{\circ} 50^{\prime} 0^{\prime \prime} \mathrm{S}$ and $107^{\circ} 45^{\prime}$ 0" E (Top-Right) covering some part of Subang Regency, West Bandung Regency, Bandung Regency, Garut Regency, Bandung City and Cimahi City. Such land cover rapid changes exert a pressure on land quality which in turn impacts changes in land suitability and lead to the complexity in land variables evaluation.

Geographically, Study area is a part of Bandung basin region where situated in a tropical climate region, with quite dynamic changes in land cover and high erosion 
records that indicated by the high levels of sedimentation on Citarum watershade and sub-watershade, have made a unique complexity in an erosion study.

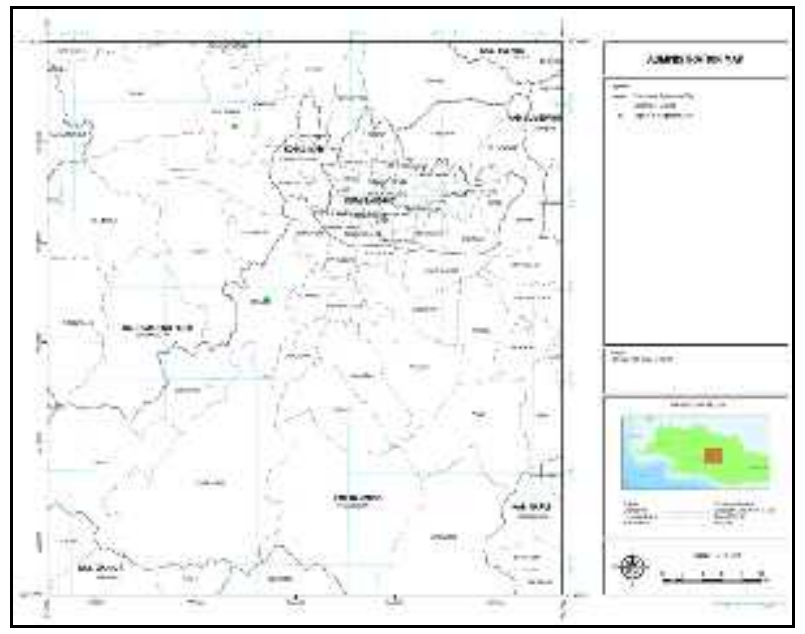

Figure 1 Map of study area

\section{Data and Methodology}

\subsection{Data}

The data used in the present research was Landsat TM 5 satellite imagery data, SRTM data, rainfall map and soil type map.

\subsubsection{Landsat Satellite Image Data}

Image data used was Landsat 5 Thematic Mapper band 1,2,3,4,5 and 7 recorded on 29th June 2009, Which has coresponding year with other secondary data like soil types map, rain fall map and SRTM data. The Landsat remote sensing system uses a passive sensor comprising 7 bands that is sensitive to the ranges of visible and infrared waves. The specification of each band according to USGS (2013) is as follows:

Table 1 Bands of Landsat 5 TM

\begin{tabular}{|l|c|c|}
\hline \multicolumn{1}{|c|}{ Band No. } & Range & Resolution \\
\hline Band 1 Visible & $(0.45-0.52 \mu \mathrm{m})$ & $30 \mathrm{~m}$ \\
\hline Band 2 Visible & $(0.52-0.60 \mu \mathrm{m})$ & $30 \mathrm{~m}$ \\
\hline Band 3 Visible & $(0.63-0.69 \mu \mathrm{m})$ & $30 \mathrm{~m}$ \\
\hline Band 4 Near-Infrared & $(0.76-0.90 \mu \mathrm{m})$ & $30 \mathrm{~m}$ \\
\hline Band 5 Near-Infrared & $(1.55-1.75 \mu \mathrm{m})$ & $30 \mathrm{~m}$ \\
\hline Band 7 Mid-Infrared & $(2.08-2.35 \mu \mathrm{m})$ & $30 \mathrm{~m}$ \\
\hline
\end{tabular}

Landsat image is used to generate NDVI (Normalized Difference Vegetation Index) value. Its values vary from 0 to 1 and obtained from visible band 3 and infrared band 4 using NDVI equation. Healthy plants have a high NDVI value because of their high reflectance of infrared light, and relatively low reflectance of red light (CCRS, 2000)

\subsubsection{Rainfall Data}


The rainfall data used was the rainfall maps published by West Java Province Development Planning Agency Office issued in 2010 (RTRW of West Java, 2010).

\subsubsection{Soil Types Data}

The soil type data was used for soil erodibility factor calculation. The soil types map used derivated from the soil types data published by West Java Province Development Planning Agency Office of issued in 2010 (RTRW Of West Java, 2010).

\subsection{Methodology}

Changes in both vegetation and topography variables are closely related to human dynamics. Some erosion models applied to estimated erosion rates had been used by earlier researchers, among others, Universal Soil Loss Equation (USLE) model. According to Wischemeier and Smith (1960), if climate factor is substituted by rain erosivity factor ( $R$ ) then the formulation of USLE is changed into RUSLE (revised Universal Soil Loss Equation). RUSLE model is also appropriate to use in estimating erosion rates in a watershade (Millward and Mersey, 1999) which is Bandung basin has many watershade.

The RUSLE equation, according to Wischemeier and Smith (1960 and 1978), is as follows:

$$
\mathrm{E}=\mathrm{R} \times \mathrm{K} \times \mathrm{L} \times \mathrm{S} \times \mathrm{C} \times \mathrm{P}
$$

$\mathrm{E}=$ Average annual soil erosion (ton/ha/year)

$\mathrm{R}=$ Rainfall erosivity factor $(\mathrm{mm} /$ year)

$\mathrm{K}=$ Soil erodibility factor (ton/ha)

$\mathrm{L} \quad=$ Slope length factor $(\mathrm{m})$

$\mathrm{S} \quad=$ Slope steep factor $(\%)$

$\mathrm{C}=$ Vegetation factor

$\mathrm{P}=$ Support practice factor

The methodology of research was described as follows: 


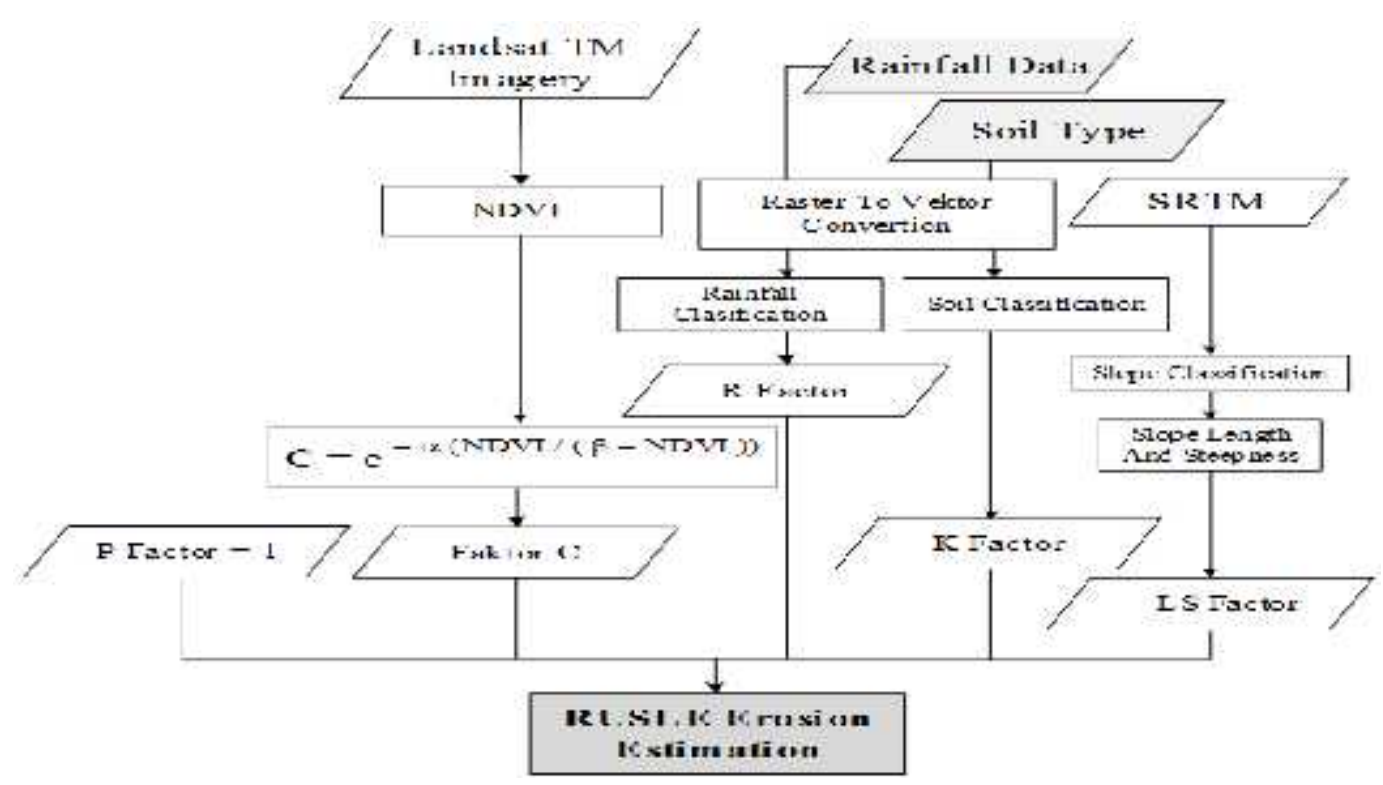

Figure 2 Methodology

\subsubsection{Rain Erosivity Factor $(\mathbf{R})$}

The study area was in a wet climate area, where waters are the main cause of the occurrence of erosion relative to winds. The contribution of waters was strongly affected by the variables of rain intensity, rainfall, and rain distribution. The estimation of erosion caused by rains based on earlier research of IITA (International Institute of Tropical Agriculture). IITA made an approach of multiplication of maximum rainfall where $\mathrm{R}$ was computed by using a maximum annual rainfall; and by using a simpler equation :

$$
\mathrm{R}=0.41 \times \text { (maximum rainfall) }{ }^{1.09}
$$

The rainfall data was acquired from rainfall maps in a raster format. The rainfall raster maps were then converted into a vector format by a digitation process. The digitation yielded rainfall class in polygon. The polygons per rainfall class were discretized into a $30 \mathrm{~m} \times 30 \mathrm{~m}$ area. Using equation (2), the value of each discretized polygons was computed. The relationship between rainfall unit and rain erosivity factor was contained on the table 2 .

Table 2 Rainfall erosivity (Calculations Product, 2010)

\begin{tabular}{|c|c|}
\hline \multicolumn{2}{|c|}{ Rain Erosivity Index ( R ) } \\
\hline Rainfall & R \\
\hline $1000-1500$ & $1,187.75$ \\
\hline $1500-2000$ & $1,625.20$ \\
\hline $2000-2500$ & $2,072.71$ \\
\hline $2500-3000$ & $2,528.40$ \\
\hline $3000-3500$ & $2,991.01$ \\
\hline $3500-4000$ & $3,459.63$ \\
\hline $4000-4500$ & $3,933.56$ \\
\hline $4500-5000$ & $4,412.26$ \\
\hline $5000-5500$ & $4,895.30$ \\
\hline $5500-6000$ & $5,382.31$ \\
\hline
\end{tabular}




\subsubsection{Soil Erodibility Factor (K)}

Soil erodibility is a sensitivity of soil type on erosion. K factor in RUSLE model is soil erodibility factor, defined as erosion rate per rain erosion index $(\mathrm{R})$ for soil obtained from a standard experimental plot, considerly an experimental plot 72.6 feet $(22 \mathrm{~m})$ long, located on a slope $9 \%$, without vegetation. Based on the variables in the erodibility equation, the erodibility ( $\mathrm{K}$ factor) of various types of soil was arranged in Table 3. (Soemarwoto, 2009).

Table 3 Soil erodibility factor

\begin{tabular}{|c|c|c|c|}
\hline \multicolumn{4}{|c|}{ Soil Erodibility } \\
\hline Soil Type & K & Soil Type & K \\
\hline Alluvial & 0.29 & Litosol & 0.13 \\
\hline Andosol & 0.28 & Mediteran & 0.16 \\
\hline Brown Forest & 0.28 & Organosol & 0.29 \\
\hline Glei & 0.29 & Podsol Merah & 0.20 \\
\hline Glumusol & 0.16 & Regosol & 0.31 \\
\hline
\end{tabular}

The data of soil types was obtained from the soil type raster map then converted into a vector format in ArcGIS environment.

\subsubsection{Slope gradient $(L)$ and Slope Length (S)}

The slope gradient was notated by L, defined as the slope length factor measured from the location of the beginning of water flow occurrence above soil surface to the location of the beginning of precipitation (Arsyad, 2010). The slope length or S is a slope steepness factor. According to Arsyad (2010), slope steepness is expressed in slope angle degree or percent $(\%)$.

In practice, the values of $\mathrm{L}$ and $\mathrm{S}$ are computed simultaneously in form of a LS factor. Thus, LS is defined as a ratio of the extent of erosion of a land area in a certain length and steepness to that of the same land with slope length of $22 \mathrm{~m}$ and steepness of 9\%. The value of LS of a land can be computed by the following equation (Arsyad, 2010):

$$
\mathrm{LS}=\left(\mathrm{x}\left(0.0138+0.00965 \mathrm{~g}+0.00138 \mathrm{~g}^{2}\right)\right)^{0.5}
$$

where,

$\mathrm{g}=$ slope steepness in percent.

$\mathrm{x}=$ slope length in meter.

Based on the equation (3), slope gradient factor (LS) can be found from the slope steepness. LS classification based on the class of slope steepness is contained in Table 4.

Table 4 Slope factor (Arsyad, 1989)

\begin{tabular}{|c|c|c|}
\hline No. & SLOPE & LS \\
\hline 1 & $0-8 \%$ & 0.4 \\
\hline 2 & $8-15 \%$ & 1.4 \\
\hline 3 & $15-25 \%$ & 3.1 \\
\hline 4 & $25-40 \%$ & 6.8 \\
\hline
\end{tabular}




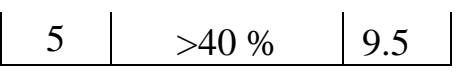

\subsubsection{Vegetation Cover Factor $(C)$}

Vegetation cover factor/C factor is determined according to the value of NDVI (Normalized Difference Vegetation Index) obtained from Landsat TM 5 imagery processing using bands 4 and 3. The images used have been subjected to radiometric and geometric corrections based on coordinate data from an Indonesia Topographic Map, scale $1: 25.000$. The denser the vegetation cover, the closer the value of NDVI to 1 ; and the sparser the vegetation cover, the closer the value of NDVI to 0 (0 (sparse) < NDVI < 1 (dense)). However, for the value of $\mathrm{C}$ the opposite rule applied. For example, according to Asis (2006), the value of $\mathrm{C}$ factor for forest is 0 and for bare land is 1 .

Vegetation index/NDVI is a mathematic algorithm for measuring vegetation canopy greenness optically, composite nature of leaf chlorophylls, leaf width, and vegetation canopy structure and cover (Huete, 2011), computed using ENVI ver 4.2 software and considering a negative correlation between surface temperature and NDVI vegetation spectral index (Moran et. al., 2004).

$$
\text { NDVI }-\frac{\text { NIR }-R_{\text {red }}}{\text { NIR }+R_{\text {edd }}}
$$

NIR $=$ Near Infrared channel

Rred $=$ Red channel

European Soil Bureau develops a model of the relationship between NDVI and C factor in equation 5 (Kniff, 1999)

$$
\mathrm{C}=\mathrm{e}^{-} \quad(\mathrm{NDVI} /(-\mathrm{NDVI}))
$$

$\alpha$ and $\beta$ are the parameters determining the contour of NDVI $-\mathrm{C}$ curve. The values of $\alpha=$ 2 and $\beta=1$ are recommended by Knijff (1999). Sulistiyo (2011) simplifies equation (5) into a nonlinear exponential function as follows:

$$
Y=\alpha e^{(\beta X)}
$$

where:

$\mathrm{Y}=\mathrm{C}$ Factor

For this research, $\mathrm{X}$ represent a NDVI Value.

Actually existed some vegetation index model can be applied but we use NDVI with some consideration of literary study. De Jong, et al (1994); Lin, et al (2002), Knijff, et al (2002) and Suriyaprasit (2008) in Alenjandro M, in their research try to correlate C factor from NDVI. De Jong and Lin found linear correlation between NDVI and C meanwhile Van der Knijff et al, and Suriyaprasti found that correlation between $\mathrm{C}$ factor and NDVI accepted in non linear form with exponential function (Sulistyo, 2011) and Arsyad (1989) compare non linear exponential function to linear function with correlation value 0.08 for linear and 0.84 for non linear. According to earlier research background, $\mathrm{C}$ factor calculated from NDVI as following chart. 


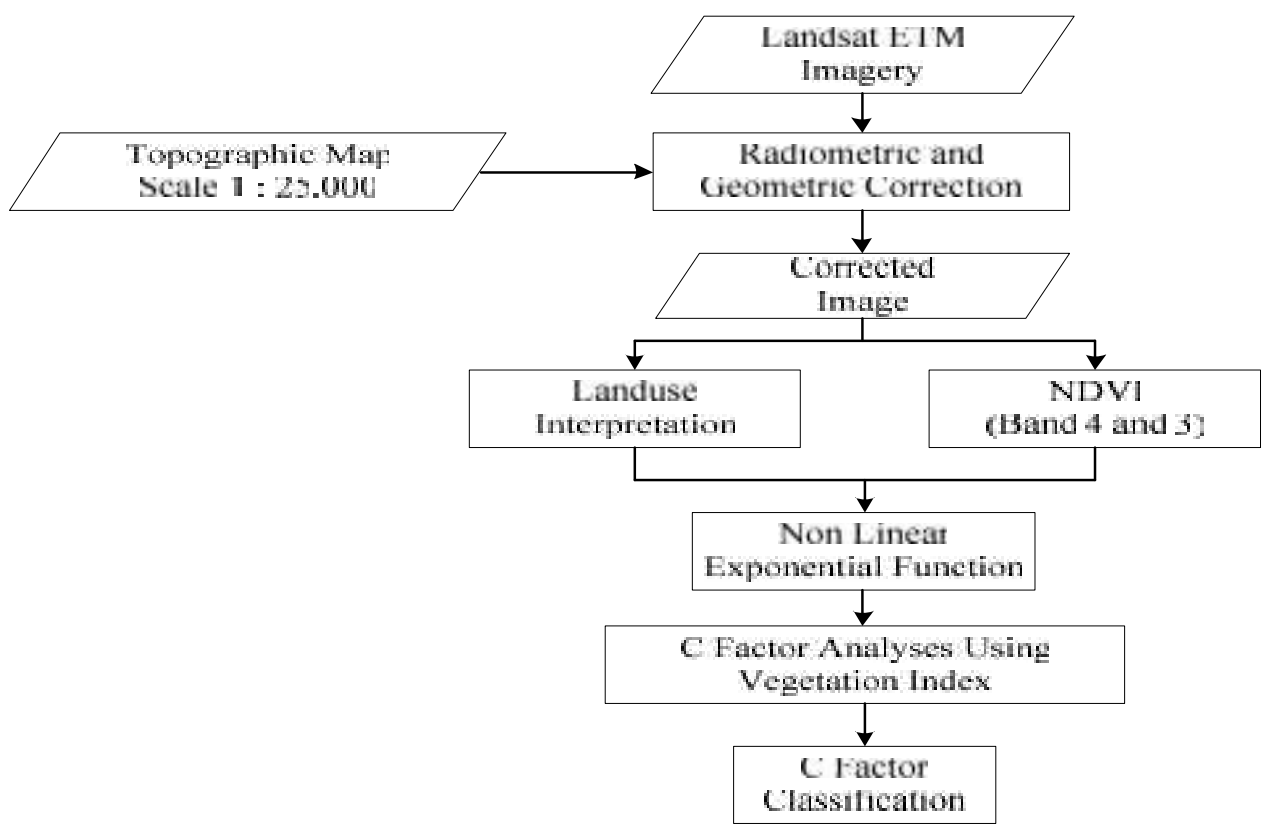

Figure $3 \mathrm{C}$ factor flowchart from NDVI

\subsubsection{Support Practice (P)}

Support practice or $\mathrm{P}$ factor is a particular conservation implemented to study area or ratio of soil erosion of the soil with conservation treatment like terracing, crop pattern to total soil erosion managed in line of slope in identical circumstances. For this research $\mathrm{P}$ factor considered as 1 . $\mathrm{P}$ factor related strongly with land conservation.

\section{Analyses and Result}

Erosion class distribution analysed using ArcGIS software, which is integrate all related erosion factor in geospatial database. All factors like Slope, Soil type converted into point data as well as for $\mathrm{C}$ factor. $\mathrm{C}$ factor derivate from NDVI and NDVI calculated using band 3 and 4 of landsat imagery. Since landsat format was in pixel format, all data converted into point format and within ArcGIS environment RUSLE model calculated to obtain distribution of erosion rate value.

Spatial analyses result show that study area dominated by two regencies, Bandung regency and West Bandung regency. Erosion rate classified it into 5 class erosion level ; very light erosion (< 15 ton/ha/year), light ( $15-60$ ton/ha/year), moderate (60 -180 ton/ha/year), Heavy erosion (180-480 ton/ha/year), Very Heavy (> 480 ton/ha/year). Erosion rate classification refered to erosion velocity prediction (ton / ha / year) and soil destruction control policy for biomass product with stressing on soil solum criteria, critical erosion threshold and to Erosion Hazard Level reference. 
Spatially erosion value distribution as the result of RUSLE modeling for whole of study area illustrated in Arcg GIS software as follow.

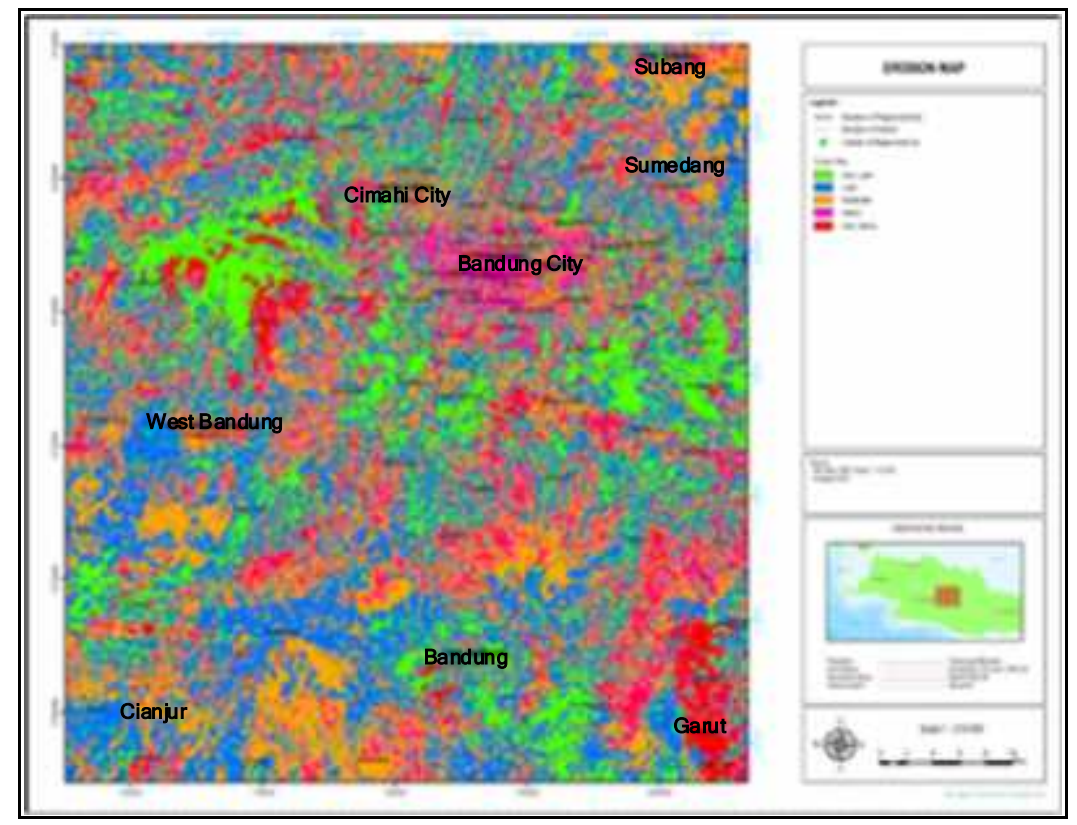

Figure 4 Erosion rate distribution

Within study area, erosion rate generally distibuted in class of moderate and low with average cover $37 \%$ and $34 \%$ of total study area. As showe in figure 4, heavy erosion class is shown by Garut regency with $27 \%$, this class mostly effected by topographical aspect or represent by slope length and slope steepness (LS). Garut regency topographic in the north part mostly consists of highland and mountainous, while in the south part consist of deep steep slope.

Erosion result for Subang regency show mostly in moderate level in $57 \%$ of the area studied, Subang surrounded by deep steep slope in the border with West Bandung and Sumedang, the existed of tea plantation in such area hold erosion in moderate level. Overall erosion rate based on GIS analyses result arranged in following table 5 covering study area.

Table 5 Spatial analyses result

\begin{tabular}{|c|c|c|c|c|c|c|c|}
\hline \multirow{2}{*}{$\begin{array}{c}\text { Regency / } \\
\text { Town }\end{array}$} & & \multicolumn{5}{|c|}{ Erosion Class (Hectare and Percentage) } & \multirow{2}{*}{$\begin{array}{c}\text { Grand } \\
\text { Total }\end{array}$} \\
\cline { 3 - 7 } & $\begin{array}{c}\text { Very } \\
\text { Light }\end{array}$ & Light & Mod & Heavy & $\begin{array}{c}\text { Very } \\
\text { Heavy }\end{array}$ & 146.3 \\
\hline Bandung Reg. & $\mathrm{Ha}$ & 23.54 & 54.6 & 49.0 & 14 & 4.754 & 14.3 \\
\hline $\begin{array}{c}\text { West Bandung } \\
\text { Reg. }\end{array}$ & $\mathrm{Ha}$ & 14.93 & 31.5 & 27.1 & 7.6 & 4.994 & 86.24 \\
\hline Cianjur Reg. & $\mathrm{Ha}$ & 615 & 4.77 & 3.86 & 740 & 331 & 10.32 \\
\hline Garut Reg. & $\mathrm{Ha}$ & 484 & 2.63 & 2.97 & 1.1 & 2.669 & 9.868 \\
\hline Bandung & $\mathrm{Ha}$ & 1.704 & 4.30 & 6.16 & 4.9 & 193 & 17.24 \\
\hline Cimahi & $\mathrm{Ha}$ & 734 & 1.39 & 1.48 & 673 & 174 & 4.445 \\
\hline Subang Reg. & $\mathrm{Ha}$ & 95 & 640 & 1.62 & 411 & 73 & 2.842 \\
\hline
\end{tabular}




\begin{tabular}{|c|c|c|c|c|c|c|c|}
\hline $\begin{array}{c}\text { Sumedang } \\
\text { Reg. }\end{array}$ & Ha & 497 & 2.08 & 1.49 & 209 & 22 & 4.293 \\
\hline Total & Ha & $\mathbf{4 2 . 6 0}$ & $\mathbf{1 0 2 . 0 6}$ & $\mathbf{9 3 . 6 9}$ & $\mathbf{3 0 . 0 6 8}$ & $\mathbf{1 3 . 2 0 9}$ & $\mathbf{2 8 1 . 6 4}$ \\
\hline
\end{tabular}

Analyses result validation carried out by comparative study between study results with existing erosion map of West Java Province published by Development Planning Agency Office of West Java Province (BAPPEDA) with random sampling. Statistically, error possibilities are in range 5\% and $1 \%$ in comparation of erosion class from BAPPEDA's erosion map to erosion class from this research. For every single erosion class we took 150 samples, totally there are 750 samples representing study area. The number of sample based on normal distribution $3.3 \log n+1$. According to statistic calculation, sampling result show data validity variation is on $2.38 \%$ or $1.19 \%$ for deviation. Based on sampling confidence level show that for error possibility 5\% or confidence level $95 \%$ is on 0.191876 , meanwhile for $1 \%$ or confidence level $99 \%$ is on 0.318183 .

An analysis of accuracy was also conducted by finding the value of Kappa coefficient. A cross matrix between BAPPEDA erosion and the result of study was as follows:

Tabel 6 Erosion class cross matrix

\begin{tabular}{|r|c|c|c|c|c|c|}
\hline \multirow{2}{*}{$\begin{array}{c}\text { Erosion } \\
\text { Class }\end{array}$} & \multicolumn{5}{|c|}{ Erosion Check Result } & \multirow{2}{*}{ Total } \\
\cline { 2 - 6 } & $\begin{array}{c}\text { Very } \\
\text { Light }\end{array}$ & Light & Moderate & Heavy & $\begin{array}{c}\text { Very } \\
\text { Heavy }\end{array}$ & \\
\hline Very Light & 198 & 25 & 23 & 23 & 37 & $\mathbf{3 0 6}$ \\
\hline Light & 34 & 55 & 26 & 6 & 10 & $\mathbf{1 3 1}$ \\
\hline Moderate & 26 & 7 & 74 & 0 & 21 & $\mathbf{1 2 8}$ \\
\hline Heavy & 0 & 0 & 0 & 39 & 13 & $\mathbf{5 2}$ \\
\hline Very Heavy & 0 & 0 & 9 & 13 & 111 & $\mathbf{1 3 3}$ \\
\hline & $\mathbf{2 5 8}$ & $\mathbf{8 7}$ & $\mathbf{1 3 2}$ & $\mathbf{8 1}$ & $\mathbf{1 9 2}$ & $\mathbf{7 5 0}$ \\
\hline
\end{tabular}

From the cross matrix data it could be seen that the erosion rate in the study area fell into a very light erosion class. This was in agreement with on site observation indicating that in general, support practice had been carried out in the study area, particularly by modifying the contour of land surface into a terrace. The analysis of cross matrix accuracy was as follows:

Accuracy per class,

$\begin{array}{rr}\text { Very Light } & 77 \% \\ \text { Light } & 63 \% \\ \text { Moderate } & 56 \% \\ \text { Heavy } & 48 \% \\ \text { Very Heavy } & 58 \%\end{array}$

Accuracy of total sample was $(198+55+74+39+111) / 750=64 \%$

The average accuracy in very light classes was $77 \%$. Based on the result of verification in the field, the topographic shape of the study area has generally received a conservatory action in form of terrace. 
Based on the cross matrix, the value of Kappa coefficient of the erosion sample distribution was 0.518 , or assumed as falling into a category of satisfied.

\section{Conclusion}

Visible and Near Infrared wave range of satellite imagery are applicable for erosion analyses by applying non linear exponential function to derivate $\mathrm{C}$ factor value. From all of six factor in RUSLE model, five factor considered relatively static to $\mathrm{C}$ factor which $\mathrm{C}$ factor correlate to land cover using non linear exponential approach as function of NDVI, whereas for study area, population density grow rapidly and changed land cover into significant level within short period.

Satellite imagery can be used for erosion prediction analyses in a large area, relatively faster comparing to direct observation. C factor derivation from NDVI is one of another 5 factors in erosion modeling using RUSLE until required advance research to involve another 5 factors derivate from satellite imagery. All RUSLE parameter calculated simultaneously in GIS environment to yield spatial distribution of erosion rate.

\section{Reference}

Alejandro M., de Asis, Omasa K., Estimation of Vegetation Parameter For Modeling Soil Erosion, ISPRS Journal of Photogrammetry \& Remote Sensing 62 (2007) 309-324 (2007).

Arsyad, S. (2010): Konservasi Tanah dan Air, Edisi kedua, IPB Press Bogor.

Blanco H, Humberto, Lal, Rattan. (2008) : Principle Of Soil Conservation And Management. Springer.

CCRS (2000) ; Fundamentals Of Remote Sensing The Canada Centre for Remote Sensing (www.ccrs.nrcan.gc.ca/resource/ tutor/fundam/index_e.php)

De Jong, S.M., 1994. Derivation of vegetative variables from a Landsat TM image for modeling soil erosion. Earth Surface Processes and Landforms 19 (2), pp. 165-178.

Gobena, Y.J (2003) : Soil Erosion Assesment Using Remotely Sensed. ITC, Netherland.

Huete A., Prasad S. Thenkabail, John G. Lyon (2011): Hyperspectral Remote Sensing of Vegetation. ISBN 9781439845370 - CAT\# K12019. CRC Press

Knijff V. D., Jones, J. M., Montanarella, L. (1999): Soil Erosion Risk Assesment In Italy, European Soil Bureau, Joint Research Center Of Comission.

Knijff V D., J.M., Jones, R.J.A., Montanarella, L. (2002) : Soil Erosion Risk Assessment in Italy. In: J.L. Rubio, R.P.C Morgan, S. Asins and V. Andreu (eds). Proceedings of the third International Congress Man and Soil at the Third Millennium. Geoforma Ediciones, Logroño. pp.1903-1913. 
Lin, C. Y. (2002): Soil Erosion Prediction And Sediment Yield Estimation, The Taiwan Experience, Soil And Tillage Research, 68 (2), pp.143-152.

Meer V.D and Jong, S. (2004) : Remote sensing image analysis: including the spatial domain. Kluwer Academic Publishers, Dordrecht, the Netherlands, 375 pp., ISBN 14020-2559-9. Observation and Geoinformation, 8: pp. 3-17.

Milward A. A and Mersey J. E., 1999. Adapting The RUSLE To Model Soil Erosion Potential In A Mountainous Tropical Watershade. Catena, Volume 38, Issue 2, pp. 109 129.

Moran M.S., Peters C.D, Watts J.M., dan McElroy S., (2004): Estimating Soil moisture at the watershed scale with satellite-based radar and land surface models, Can. J. Remote Sensing, Vol. 30, No. 5, pp. 805-826

Morgan, R.P.C., (2005): Soil Erosion And Conservation, Third Edition, Blackwell Publishing.

Rencana Tata Ruang Wilayah /RTRW Provinsi Jawa Barat (2010) : Badan Perencanaan Pembangunan Daerah (BAPPEDA) Jawa Barat.

Soemarwoto, (2009) : Analisis Mengenai Dampak Lingkungan. UGM Press.

Seta, A. K. (1987). Konservasi Sumberdaya Tanah dan Air. Kalam Mulia, Jakarta.

Suriyaprasit, M. (2008) : Digital terrain analysis and image processing for assessing erosion prone areas : a case study of Nam Chun watershed, Phetchabun, Thailand. Enschede, ITC.

Sulistyo B. Gunawrti T., Hartono, Danoedoro., (2010). Pemetaan Faktor C Dari Data Penginderaan Jauh, Manusia dan Lingkungan Vol 18 (2011).

Tao C., Niu R.Q, Li P., Zhang L.P, Du B. (2010) ; Regional soil erosion risk mapping using RUSLE, GIS, and remote sensing: a case study in Miyun Watershed, North China. Environ Earth Sci, DOI 10.1007/s12665-010-0715-z.

USGS, (2013) : Landsat 5 History. http://landsat.usgs.gov/_about_landsat5.php

Wischmeier and Smith, (1960) ; Empirical Soil Loss Model (USLE), FAO Corporate Document Repository.

Wischmeier. W.H and Smith D.D., (1978). Predicting Rainfall Erosion Losses a Guide to Conservation Planning. Washington DC:USDA.

Wischmeier and Smith, (1960) ; Empirical Soil Loss Model (USLE), FAO Corporate Document Repository.

Wischmeier. W.H and Smith D.D., (1978). Predicting Rainfall Erosion Losses a Guide to Conservation Planning. Washington DC:USDA 